Canadian Journal of Higher Education Revue canadienne d'enseignement supérieur

Volume 46, No. 2, 2016, pages 40 - 54

\title{
Enhancing Care and Advocacy for Sexual Assault Survivors on Canadian Campuses
}

Elizabeth Quinlan

University of Saskatchewan

Allyson Clarke

Saskatchewan College of Psychologists

Natasha Miller

University of Saskatchewan

\begin{abstract}
Recent media coverage of the rape chant at Saint Mary's University, the misogynist Facebook posts at Dalhousie's dental school, and the suspension of the University of Ottawa's hockey team have brought the topic of campus sexual assault under intense public scrutiny and the media accounts point to a widespread systemic rape culture on Canadian campuses. The objective of this paper is to examine the existing structure of campus sexual assault services at Canadian universities and colleges in order to highlight best practices and barriers to their success. The study's data collection entailed an environmental scan of existing programs and campus-community collaborations across Canada, and a half-day symposium in which stakeholders reviewed the scan's results and developed recommendations. The study's findings indicate that most campus sexual assault and women's centres rely on volunteers and collaboration with off-campus organizations in order to maintain a breadth of services for sexual assault survivors. Funding challenges were found to impose significant limitations to the functionality of the centres. The paper closes with recommendations for improvements, including public education programming and dedicated services provided by professionals with specialized training and experience.
\end{abstract}




\section{Résumé}

La récente couverture médiatique provoquée par un chant d'initiation encourageant le viol à l'UniversitéSaint Mary, des messages misogynes affichés sur la page Facebook del'école de dentisterie del'Université Dalhousieà Halifax et la suspension de l'équipe de hockey de l'Université d'Ottawa a mis sur la sellette les agressions sexuelles sur les campus. Toutes ces situations ont fait l'objet d'un examen attentif du public et confirment une culture du viol sur les campus canadiens. L'objectif de la présente étude est d'examiner la structure existante des services d'intervention en matière d'agression sexuelle sur les campus des universités et des collèges du Canada pour mettre en évidence les meilleures pratiques et les obstacles à leur réussite. Les données de l'étude comportent une analyse environnementale des programmes existants et de la collaboration entre campus et collectivités partout au Canada, ainsi qu'un symposium d'une demi-journée lors duquel des intervenants ont examiné les résultats de l'analyse environnementale, puis soumis leurs recommandations. Les résultats de l'étude indiquent que la plupart des centres pour femmes et des organismes de défense contre les agressions sexuelles comptent sur des bénévoles et une collaboration avec des organismes hors campus pour maintenir l'étendue des services offerts aux victimes d'agression sexuelle. Par ailleurs, des difficultés financières ont imposé des limites importantes à la fonctionnalité des centres. L'étude conclut en recommandant d'apporter des améliorations, dont la mise en œuvre de programmes d'éducation du public et l'offre de services fournis par des professionnels expérimentés détenant une formation spécialisée.

\section{Introduction}

Despite ongoing educational efforts, sexual assault ranks in the top five violent crimes against women in Canada (Sinha, 2013). Although sexual assaults occur in a variety of environments (e.g., bars, restaurants, homes), university and college campuses are among the most common sites (Kong, Johnson, Beattie, \& Cardillo, 2003). Campuses, particularly large urban campuses, are sexual assault "hot spots" due to the convergence of several factors known to increase women's vulnerability and crime in general. Student populations are disproportionately young and transient, with low levels of group cohesion and community attachment, both factors known to affect crime rates in general. Another factor is that students have higher rates of alcohol and drugs consumption (Krug, Dahlberg, Mercy, Zwi, \& Lozano, 2002). Research on the link between alcohol consumption and sexual victimization confirms that sexual aggressors take advantage of the permissive environment in bars and other public drinking establishments to initiate predatory sexual overtures (Graham, Bernards, Abbey, Dumas, \& Wells, 2014; Graham, Wells, Bernards, \& Dennison, 2010). In Canada drug-facilitated sexual assault has shown a notable and sustained increase among younger women in the last 15 years (McGregor, Ericksen, Ronald, Janssen, Vliet, \& Schulzer, 2004).

Little has been written about the Canadian context of sexual violence on campuses. However, the recent media coverage of the rape chant at Saint Mary's University (Taber, 
2013), the misogynist Facebook posts at Dalhousie dental school (Jeffrey, 2014), and the suspension of the University of Ottawa's hockey team (CBC News, 2015; Ormiston, 2014) have brought the topic under intense public scrutiny and point to a widespread systemic culture of rape, casual intimidation, and trivializing of under-aged rape on Canadian campuses. A survey on date rape showed that $60 \%$ of Canadian college-aged males indicated that they would commit sexual assault if they were certain they would not get caught (Lenskyi \& Ontario Institute for Studies in Education, 1992).

In Canada, students have significantly higher rates of sexual assault in comparison to those whose main activity is paid work in the labour market (Brennan \& Taylor-Butts, 2008). DeKeseredy and Schwartz (1997) found that $28 \%$ of female undergraduates at Canadian colleges and universities reported being victims of sexual abuse. More recently, results of a study by Senn et al. (2014) showed no improvement in prevalence of sexual abuse, with 35\% of first-year university women experiencing at least one completed or attempted rape since age 14 . The actual rates might be greater due to potential under-reporting.

Victims of sexual assault often feel ashamed and responsible for the assault since prevailing views identify the problem with women's behaviour and many men and women, including victims, do not realize that sexual assault is a crime (Kilpatrick, Resnick, Ruggiero, Conocsenti, \& McCauley, 2007). Furthermore, inadequately trained faculty and staff to whom victims disclose a sexually violent experience might dismiss or discount the incident for fear of the negative repercussions for the institutions' reputation. Sexual assault committed by an acquaintance has particularly high rates of under-reporting (Rajacich, Fawdry, \& Berry, 1992).

As a prerequisite to receiving federal funds, legislation in the United States requires colleges and universities to collect and disclose campus crime statistics, including sexual crimes; implement a student bill of rights for both the complainant and accused; and notify the campus community of threats to their safety. Compliance with the Clery Act, named in honour of a student who was sexually assaulted and murdered on her campus, has been slow. In 2002, over a decade following the passage of the legislation, only slightly more than a third of institutions were fully compliant (Gonzales, Schofield, \& Schmitt, 2002), and estimates of the prevalence of sexual assault are alarmingly consistent with those prior to the enacted legislation in the early 1990s (Gidycz, Rich, \& Orchowski, 2006). Although the recent Ontario government's action plan, It's Never Okay, (Minister Responsible for Women's Issues, 2015) promises imminent legislation to require Canadian colleges and universities to adopt campus-wide sexual violence policies, no such legislative requirements currently exist in Canada, and program implementation tends to be driven by legal actions (e.g., Pinchin, 2009). In contrast to the US, data on campus crime in Canada is not collected, analyzed, or distributed systematically (for exceptions see CBC, 2015), partly because security forces on Canadian campuses rarely constitute separate police jurisdictions with standardized data collection and reporting, as is the case in the US.

Feminist scholars such as Ann Cahill (2001) propose that sexual assault is best understood in terms of a cultural phenomenon with prevailing norms and perceptions tending to equate "feminine" roles and behaviours with subservience to men's (supposedly uncontrollable) sexual needs. Accordingly, there is no typical sexual assault, victim, or perpetrator, although certain groups of women are more likely to be victims (Koss, Gidycz, \& Wisniewski, 1987). For instance, the particular vulnerability of Aboriginal women is 
also reflected in the large number of missing and murdered victims, currently estimated to be over 1,100 (RCMP, 2015). Moreover, there are no typical physical or psychological impacts. Sexual assault has immediate and long-term health consequences for victims including suicide, HIV infection, depression, and social isolation (Krug et al., 2002). College victims are at a higher risk of depression and post-traumatic stress disorder than their non-campus counterparts (Kilpatrick et al., 2007). Sexual violence against students is known to affect victims' quality of life and negatively impacts their academic success because of the disruption of moving residences, disengagement in their classes, and increased likelihood of dropping out (Huerta, Cortina, Pang, Torges, \& Magley, 2006; Jordan, Combs, \& Smith, 2014; Smith, White, \& Holland, 2003; Tremblay et al., 2008). Of the over 4,00o women in Fisher, Daigle, and Cullen's's (2010) National College Women Sexual Victimization Study, over 40\% of the rape victims experienced emotional or psychological injuries. In addition, sexual assaults affect not only the victims. By conveying the message that personal safety is not something women can assume, each sexual assault has sinister effects on all women (Cahill, 2001).

The purpose of this paper is to report results of an environmental scan of campus sexual assault centres in order to highlight best practices, barriers to success, and present key recommendations. In doing so, the paper offers concrete means of reaffirming student health and safety as an overarching institutional priority. Although the article focuses on women as sexual assault victims, this is not to suggest that they are the only victims of sexual assaults, but they are the overwhelming majority.

\section{Methods}

The two-stage data collection for the study entailed an environmental scan of existing programs and collaborations across Canada and a half-day symposium, held with stakeholders located in a mid-size western-Canadian city, to review the environmental scan results and develop recommendations. The collection and analysis of each form of data are described below. Ethics approval was deemed to be unnecessary by the authors' university ethics review board based on its reading of Article 2.1 of the Tri-Council Ethics Policy, which exempts research involving individuals who themselves are not the focus of the research.

\section{Environmental Scan}

Two hundred and forty-three Canadian postsecondary colleges and universities were identified at Universities and UnivSource, and the websites of each were reviewed. Based on this review, as well as inquiries sent to campus and student union representatives, a sample of 54 institutions were found to have a designated sexual assault centre or women's centre. Requests were sent to each centres' email addresses. We described the study and requested an appropriate staff person complete a standardized questionnaire that consisted of 24 open-ended questions regarding services provided, organizational structure, and level of collaboration with other campus and community organizations. Thirteen centres completed the questionnaire; 12 returned it by email and one centre answered the questions over the telephone. Of the remaining 41 services contacted, three organizations responded to say that their centre did not provide services targeting sexual violence and one individual reported feeling unable to complete the questionnaire because she was new to her position. 
Data gleaned from the campus centres' questionnaire reponses was used in a second phase of the study, as reported below. Initial analysis involved thematizing the qualitative data from the completed questionnaires, comparing for congruency and determining similarities in responses (Lincoln \& Guba, 1985). The emerging themes were then refined and compared to other findings in the literature. Analysis proceeded iteratively in this fashion until saturation was reached, i.e. all data were classified and no new themes emerged (Lincoln \& Guba, 1985). This method led to the development of a number of themes concerning the organization of campus services.

Limitations. There are two main limitations to the environmental scan. First, the questionnaires were completed during the summer months and therefore those centres that are especially short staffed during July and August might be underrepresented. A related potential sample bias stems from the mode of contact. The questionnaires were sent to the contact email that appeared on their centre's website, so centres without a web presence or with an incorrect email address on their websites would not be included in the sample, even though they are in the sampling frame, which includes all the sexual assault or women's centres on Canadian postsecondary campuses. Second, the analysis did not separate college from university centres. As Seifert \& Borrow (2013) have shown, there are differences in the orientation of student services between the two types of postsecondary institutions: university students tend to be included in a wider range of roles relating to student services, such as serving on advisory committees, some of which have fiduciary responsibilities, and provide feedback on new programming initiatives (Seifert \& Borrow, 2013) while college students tend to have less formal involvement in the design of students services, perhaps because colleges tend to have units working cooperatively (e.g. academic support services connected to general support services).

\section{Symposium}

In the second phase of the study at a half-day symposium, the key findings of the environmental scan were shared with representatives from the local campus and communitybased women's organizations, including the city's sexual assault centre. The purpose of the symposium was for representatives to review and discuss the summarized scan results and offer recommendations to improve sexual assault prevention and care on campus. Thirteen advocates and service providers with various advocacy interests and expertise in diverse organizational contexts gathered. All were based in Saskatchewan, the geographical region of the researchers. With the exception of the Saskatchewan Registered Nurses Association and the sponsoring university's women's centre, all participating organizations were community-based organizations (e.g., a sexual health education network, a sexual assault information centre, an immigrant women's advocacy organization, a publically funded counselling agency, and Disappeared Women's Network, a grassroots group seeking justice for missing and murdered indigenous women). Under the guidance of a professional facilitator, the symposium followed established feminist principles of democratic decision-making, organized in a mix of small and large group discussions (Chambers, 1995). The symposium's program began with the researchers conveying the environmental scan results in summary form. An open discussion of the implications of the results and their relevance for the local context ensued. Following a lunch break, a more focused discussion on the barriers to adequate service and advocacy for sexual assault survivors, followed by a focused discussion on strategies to facilitate improvements. 


\section{Results}

\section{Environmental Scan}

Of the 13 campus sexual assault services and women's centres who completed the questionnaire, six provided dedicated sexual violence services or centres; the remaining seven reported some sexual-violence-related services, not as their overarching, but part of their larger mandate. Regardless of whether their mandate focused exclusively on responding to sexual violence or not, all centres reported providing some form of support services to victims of sexual violence (see Table 1 below).

Table 1.

Services Provided by Centres

Service Type

No. of Centres

Prevention initiatives, awareness campaigns and events such as Take Back the

10

Night, December $6^{\text {th }}$ Memorials, International Women's Day, Slut Walks, and

various forms of sexual violence awareness weeks.

Educational presentations and workshops on violence-related topics (e.g.,

10

sexual violence prevention, consent, healthy relationships, responding to dis-

closures).

Advocacy services, typically in the form of accompaniment to services (e.g., medical or legal providers) or assistance obtaining academic accommodations or other needed resources (e.g., housing, funding).

Peer or professional individual counselling.

Information resources, including websites, pamphlets, and lending libraries with resources specific to sexual violence.

All 13 centres reported that their services are designed specifically for students, but they also stated they would not turn away faculty, university staff, or community members who sought assistance. One centre reported having a designated women/womenidentified-only space, while another reported serving women, trans people, and non-gender-conforming people only. Of the remaining centres, although services tended to be focused mainly on women and trans people, all reported that services were available to those of any gender. One centre provides services for perpetrators. Another offers a program for men that is designed to help them engage with other men about sexual violence as perpetrators, bystanders, and victims.

The organizations varied in terms of whether they employ paid staff $(n=10)$ or were solely volunteer run $(n=3)$. Of those with paid staff, nine have some form of a paid coordinator who oversees a number of programs and/or the centre as a whole. In addition to those with a coordinator, four have a staff member specifically in charge of outreach or public relations, two have a staff member specifically in charge of volunteer coordination, one has a staff member responsible for financial and administrative duties, and two employ some kind of work-study position(s). Services varied in terms of whether staff 
positions are full or part time as well as whether staff are paid a wage or an honourarium. Required qualifications also vary, with the majority of organizations requiring a bachelor degree or less with considerable relevant experience. Several centres also require staff members be current students. Only one university provided professional counselling as part of its mandate, and it required its counsellor/educator hold a Master's degree.

Volunteers form a crucial labour force for campus centres that provide free services for victims of sexual assault. With the exception of the one centre with a professional counsellor/educator, all organizations rely on volunteers to assist in providing services, with the number of volunteers employed within each organization ranging from approximately 5 to 150 . Eight centres require volunteers complete a formal training program, which includes training in sexual violence issues, anti-oppression beliefs and practice, active listening and peer support, and centre policies and procedures. Volunteers are responsible for maintaining office hours and daily centre operations, providing peer support services, and outreach and educational presentations, and participating in event development and implementation. Volunteers help make the services more accessible to those who prefer a student-run program, and these positions provide students with the opportunity to acquire experience and skills, but most significantly they reduce the need for paid staff.

In addition to relying on volunteers, campus services collaborate with off-campus organizations to maintain the breadth of services for sexual assault victims. Campuscommunity collaborations are logical as campuses are public spaces and their boundaries with surrounding communities are increasingly porous (Gomme \& Micucci, 1997). The transitional zones often contain student housing, a common location of sexual assaults. The specific forms of collaboration reported by the campus centres varies greatly but commonly include providing referrals to one another, offering educational workshops and presentations, participating in on-campus research-based committees, and planning and implementing events. Seventy-eight percent of the 61 community-based centres reported collaborations with universities and colleges. Seventy percent of collaborations provided public education on sexual violence, while $55 \%$ developed and/or implemented events or campaigns. Other collaborations include the provision of medical care, collection of forensic evidence (rape kits ), and student placements and internships.

Funding for services varies and is often provided from more than one source as Table 2 indicates. Centres consider their funding to be relatively stable: on a scale of 1 to 10, with higher numbers indicating greater stability, ratings ranged from 5 to 10 , with a mean and median of 8 . However, their satisfaction with their funding was rated slightly lower, with a mean rating of 7 and a median of 7.5. Respondents identified the need for various types of resources that would require additional funding: hiring of more staff $(n=8)$, updating resource materials to increase awareness $(n=4)$, increasing physical space $(n=2)$, and expanded hours and programming $(n=2)$.

Despite the funding challenges, campus centres consider their accomplishments to be noteworthy. They include provision of both clinical and prevention services; excellent programs and events; dedicated, knowledgeable, skilled staff and volunteers; accessible and inclusive services; strong support from the student body; and opportunities for volunteers to develop meaningful skills and experiences. One particularly strong model identified in the environmental scan was a centre that receives consistent funding through a dedicated student fee. Its full-time staff, supported by rigorously trained volunteers, delivers an impressive and effective array of preventative and treatment services. 
Table 2.

Centres' Funding Sources

\begin{tabular}{lc}
\hline Funding Source & No. of Centres \\
\hline Dedicated student fees & 7 \\
Student union funding & 3 \\
University administration or other university departments & 4 \\
Fund-raising & 4 \\
Specific grant (e.g. Status of Women) & 2 \\
\hline
\end{tabular}

\section{Symposium}

The above results were presented at the symposium (the second phase of the study), from which several recommendations were formulated. Symposium participants proposed that funding should be sufficient to support campus sexual assault services that are provided by professional staff members with specialized training and experience: psychologists specializing in psychotherapy for sexual assault victims and sexual assault nurse examiners (SANEs). SANEs are a new form of public health nurse, now practising in the majority of provinces and territories. Their practice includes collection of forensic evidence (rape kits) and public education activities that target existing myths and stereotypes about sexual violence. Positioning SANEs on campuses, with an emphasis on public education activities, would serve to both prevent violence and create more supportive environments for survivors.

Key activities of the SANEs would include advocacy for sexual health and violence prevention through presentations, outreach activities, liaisons with relevant university services (e.g., counselling services, student centres, campus safety). Other sexual assault experts in the larger community would ensure continuity of care for victims and the implementation of effective prevention initiatives. While the key services might be provided by the professional staff members, symposium participants asserted that efforts should be made to recruit and train student volunteers to assist with awareness events and other programming.

Symposium participants expressed the need for comprehensive public education programming directed to changing attitudes and behaviours. They identified a need for ongoing training for faculty, staff, and students, focusing on how to respond when someone discloses a sexual assault and developing reporting options for all concerned. Further, prevention training should be grounded in an understanding of sexual assault as a normalized, socially learned behaviour. The symposium participants' views are corroborated in the literature. For instance, Cass (2007) argues that prevention programs need to shift away from notions of strangers lurking in parking lots to assailants known to the victims in spaces considered safe by the victims. Strategies that emphasize increased campus lighting and walk-safe programs tend to reinforce the stereotypical idea that assaults by strangers occur outside and at night, despite the fact that the overwhelming majority of perpetrators are friends, acquaintances, or relatives of their victims (Statistics Canada, 2009). Moreover, prevention programming directed toward women urging them to change their attitudes and reduce their "risky" conduct and improve their repertoire of 
"resistant" behaviours, such as locking doors and walking at night only if attended, have mixed and somewhat temporary results (Gidycz, Layman et al., 2001; Gidycz, Rich et al., 2001). Of greater importance, these approaches indirectly place the burden of responsibility on women, thereby encouraging women to blame themselves, which exacerbates under-reporting.

Symposium participants characterized effective public education programs as those that empower bystanders with skills to recognize and confidently intervene in risky situations, with the intention of preventing sexual assault and supporting victims who might disclose. Bystander intervention programming entails role-playing and other educational tools to teach potential interveners how and when to use formal support services (police, rape crisis centres) and how to help victims make sense of what has transpired. While this type of programming has only been recently applied to sexual assault on campuses, particularly those that employ applied theatre techniques, findings demonstrate their promise (Christensen, 2013; Mitchell \& Freitag, 2011).

\section{Discussion}

Postsecondary student populations have become more diverse, and an increasing number of older, international, and disabled students are now present on Canadian campuses. College and universities have responded to the more varied needs of their students with a plethora of programs and services to facilitate students' adaptation to campus life with the hope of decreasing attrition rates (Seifert \& Borrow, 2013). As a result, it is not surprising that campus service providers report high caseloads and increased demands on their time and, consequently, express a concern for the quality of their services (Seifert \& Borrow, 2013). This is certainly true for the campus sexual assault centres and women's centres reported in this paper.

Campus sexual assault centres have become adept at working with limited budgets by relying on volunteers and collaborating with off-campus organizations. Many have had to creatively refashion their staffing, priorities, and practices in the face of chronic budgetary constraints and persistent underfunding. These findings are congruent with those of Beres, Crow, and Gotell (2009) in relation to community-based sexual assault centres (Beres et al., 2009). As existing campus sexual assault centres continue to work hard to meet the growing demand for services, there is a pressing need for postsecondary institutions to increase their investment in preventative and intervention programming. The results of our environmental scan confirm that prevention and advocacy services on campuses are woefully inadequate: less than one-quarter (22\%) of all colleges and universities in Canada have a women's centre or a sexual assault centre-this corresponds to over 10,500 female university students in Canada for every one sexualassault/women's university centre suggests that more centres and services are in order. We speculate that the low response rate to our request to complete the questionnaire is related to the chronic under resourcing of centres that do exist. If these centres are to function with adequate space, resources, full-spectrum programming, and consistent staffing, adequate core funding is required.

Many safe-campus strategies have been proposed by others (see Nicoletti \& SpencerThomas, 2010). Some have argued that there is less need to develop new approaches than there is to sharpen the commitment to the use of existing programs (Rajacich et al., 
1992). Current proposals that are not directed to sexual violence in particular need to be considered in light of the characteristics of this particular form of violence. For instance, Dietsche's (2012) proposal for a new model of campus services that relies heavily on online components offers the advantages of anonymity; coordinates with the logistics of the everyday lives of busy, commuter students; and draws the benefits of economies of scale for the institutions (Dietsche, 2012). However, drawing from their experience as front-line advocates and care providers, this study's symposium participants expressed the view that in the face of post-sexual assault trauma, victims often prefer personal faceto-face professional or peer counselling. Trauma psychologists and SANEs form an optimal professional base to ensure that the necessary medical and psychological needs of victims are met, and these professionals can also provide much-needed public education to campus groups. The increase in drug-facilitated sexual assaults suggests the need for highly trained counsellors to address the additional difficulties wrought by amnesia and the consequences of prolonged delay in victims reporting the event and seeking help. SANEs and psychologists are well suited to develop and present targeted public educational campaigns. Combined with peer volunteers, these professionals have much to contribute to sufficiently resourced campus centres.

Campuses have a social responsibility to address sexual assault, and there are efficiencies to be gained by campus service providers working across campus-community boundaries. Both campuses and their surrounding communities are likely to make greater advances in dealing with the pervasive problem of sexual violence than each working in isolation, particularly if campus SANEs were able to cultivate connections with community sexual assault centres, campus and local police, and victim services.

The recommendations described above draw upon the strengths, while avoiding the limitations, identified by the environmental scan respondents. Using the recommendations as a spring board to develop effective and appropriate sexual assault services to complement existing structures and programs will endow campus administrations with the honourable distinction of being leaders among postsecondary institutions in their commitment to student safety, health, and well-being. There is no single omnibus strategy to achieve the laudable goal of creating safer campuses. A multilevel, multipronged approach that involves a variety of individuals, departments, units, and groups-both on-campus and in the larger community-is likely to be the most effective (Nicoletti \& Spencer-Thomas, 2010).

Currently, Canadian postsecondary institutions vary in the level of attention paid to this issue of sexual assault. Although policies addressing campus violence are on the increase, perhaps because of increased litigation, our extensive, albeit nonsystematic webbased, review of Canadian university violence policies reveals very little standardization. Sexual assault is often bundled with sexual harassment policies, the result of workplace occupational health and safety legislation, and these policies are directed to staff rather than students. Policies cannot promise to keep all faculty, staff, and students safe, but they can provide clear definitions of sexual violence, avenues for reporting sexual assault (including anonymous and third-party options), and clear investigation and notification protocols that, among other things, offer the victims full control over the pace and steps of reporting to on-campus units and off-campus law enforcement services. Victim control is particularly important, since policies that require victims to participate in identifica- 
tion of perpetrators, court proceedings, and other adjudication processes, where they will come in contact with the perpetrator, discourage victims from disclosing a sexual assault to campus security and law enforcement personnel.

Given the prevalence and impact of sexual assault, it is imperative that campuses implement wide-sweeping measures to reduce its incidence and provide victim support. Students have registered their wish for relevant education and services. In their survey of student health needs at the University of Manitoba, Katz, Davis, and Scott-Findlay (2002) found sexuality and safety issues high (28\% and $21 \%$, respectively) on the list of studentexpressed needs (Katz, et al., 2002). By directly addressing these student needs, university and colleges administrators stand to win the respect of their current and prospective students, as well as the respect of staff, faculty, and parents.

Adequate institutional responses to sexual assault entail more than simply increasing women's access to campus police, as many campuses have done. Campus security forces are sometimes the first to respond to reports of sexual assault and are often called upon to join campus committees and task forces charged with policy and program development (Spencer-Thomas \& Nicoletti, 2010). But, as crime control takes on a new emphasis among campus security forces, there is much debate about functions, structure, and orientation of campus security forces (Gomme \& Micucci, 1997). Some argue that intensifying campus policing by endowing security forces with a paramilitary structure, hiring police-trained staff, and expanding their powers to issue warrants, arrest, restrain, search, and seize adds to the public's fear of escalating campus crime. Fisher et al. (2010) found less than $5 \%$ of sexual assault victims on U.S. campuses reported the experience to law enforcement, and only half of those incidents were reported to campus police. Instead, the majority of survivors disclose their experiences to friends, family, intimate partners, or roommates (Fisher, Daigle, \& Cullen, 2010). Thus, campus programs and policies addressing sexual assault must go beyond increased security forces and reach all victims, (including those who choose not to pursue legal action) through a combination of prevention programs and support services.

Sexual assault programs and policies cannot be properly designed, implemented, and evaluated without adequate data (Gomme \& Micucci, 1997). National standards for data collection and reporting of campus sexual violence are needed. Before introducing new programs and policies and as a way of establishing a baseline measure for evaluation of the effectiveness of new programs, each institution should conduct their own campuswide assessments of prevailing attitudes towards sexual assault. Internet-based surveys make it easy to safeguard confidentiality and anonymity of participants, but focus groups allow for more in-depth data collection. These qualitative and quantitative data can be further complemented by aggregate indicators such as disciplinary cases, personal counselling referrals, and campus security reports for a comprehensive evaluation (Nicoletti \& Spencer-Thomas, 2010). In all data collection, supports for victims in the event of a disclosure are important, as are considerations to ensure the assessment process is accessible and inclusive. For instance, student union representatives need to be actively engaged in the assessment process so that the experiences and perspectives of students are fully considered. Further, planning must be based on multiple studies with a variety of data collection techniques. This paper describes but one study directed to campus administrations for planning purposes. 
It was over 20 years ago that Rajacich et al. (1992) urged universities to stop ignoring sexual violence and advocated for boards of governors to set the tone for their entire institution by committing to a comprehensive plan that reflects their vision of a safe campus and directing their senior administrative personnel and senate to implement policies and allocate resources for programs and services accordingly. This paper reiterates the call to universities administrations two decades later.

\section{Acknowledgements}

The research reported in this paper was accomplished under the auspices of a collaboration between the Coalition Against Sexual Assault - University of Saskatchewan and Community-University Institute for Social Research and was funded by the University of Saskatchewan's President's Advisory Committee on the Status of Women.

\section{References}

Beres, M., Crow, B., \& Gotell, L. (2009). The perils of institutionalization in neoliberal times: Results of a national survey of Canadian sexual assault and rape crisis centres. Canadian Journal of Sociology, 34(1), 135-163.

Brennan, S., \& Taylor-Butts, A. (2008). Sexual assault in Canada. Canadian centre for justice statistics profile series. Catalogue 85Foo33M - No. 19. Ottawa: Statistics Canada.

Cahill, A. (2001). Rethinking rape. Ithaca, NY \& London, UK: Cornell University Press.

CBCNews.(Feb. 9, 2015). Interactive: Campus sexual assault reports. Retrieved from http://www.cbc.ca/news/multimedia/interactive-campus-sexual-assault-reports1.2944538

Cass, A. (2007). Routine activities and sexual assault: An analysis of individual-and school-level factors. Violence and Victims, 22(3), 350-366.

CBC News (Jan. 16, 2015). University of Ottawa men's hockey won't ice 2015-16 team: Sexual assault allegations led to charges against two players, a fired coach and team suspension. Retrieved from http://www.cbc.ca/news/canada/ottawa/universityof-ottawa-men-s-hockey-won-t-ice-2015-16-team-1.2912592

Chambers, S. (1995). Feminist discourse/practical discourse. In J. Meeham (Ed.), Feminists read Habermas: Gendering the subject of discourse. New York, NY: Routledge.

Christensen, C. (2013). Using theatre of the oppressed to prevent sexual violence on college campuses. Trauma, Violence, and Abuse, 14(4), 282-294.

DeKeseredy W., \& Schwartz M. (1997). Women abuse on campus: A Canadian national survey. Thousand Oaks, CA: Sage.

Dietsche, P. (2012). Use of campus support services by Ontario college students. Canadian Journal of Higher Education, 42(3), 65-92.

Fisher, B., Daigle, L., \& Cullen, F. (2010). Unsafe in the ivory tower: The sexual victimization of college women. Los Angeles, CA: Sage.

Gidycz, C., Layman, M., Rich, C., Crothers, M., Gylys, J., Matorin, A., \& Jacobs, C. (2001). An evaluation of an acquaintance rape prevention program: Impact on attitudes, sexual aggression, and sexual victimization. Journal of Interpersonal Violence, 16(11), 1120-1138. 
Gidycz, C., Rich, C., Marioni, N., Lynn, S., Blackwell, L., Stafford, J., \& Fite, R. (2001). The evaluation of a sexual assault risk reduction program: A multisite investigation. Journal of Consulting and Clinical Psychology, 69(6), 1073-1078.

Gidycz, C., Rich, C., \& Orchowski, L. (2006). The evaluation of a sexual assault selfdefense and risk-reduction program for college women: A prospective study. Psychology of Women Quarterly, 30, 173-186.

Gomme, I., \& Micucci, A. (1997). Loose connections: Crime and policing on the university campus. Canadian Journal of Higher Education, 27(1), 41-68.

Gonzales, A., Schofield, R., \& Schmitt, G. (2002). Sexual assault on campus: What colleges and universities are doing about it. Washington, DC: U.S. Department of Justice, Office of Justice Programs.

Graham, K., Bernards, S., Abbey, A., Dumas, T., \& Wells, S. (2014). Young women's risk of sexual aggression in bars: The roles of intoxication and peer social status. Drug and Alcohol Review, 33, 393-400.

Graham, K., Wells, S., Bernards, S., \& Dennison, S. (2010). "Yes, I do but not with you": Qualitative analysis of sexual/romantic overture-related aggression in bars and clubs. Contemporary Drug Problems, 37(2), 197-240.

Huerta, M., Cortina, L., Pang, J., Torges, J., \& Magley, V. (2006). Sex and power in the academy: Modeling sexual harassment in the lives of college women. Personality and Social Psychology Bulletin, 32(5), 616-628.

Jeffrey, D. (Dec 15, 2014). Dal probes complaint of dentistry students promoting sexual violence. Herald News. Retrieved from http://thechronicleherald.ca/metro/1257928dal-probes-complaint-of-dentistry-students-promoting-sexual-violence

Jordan, C. E., Combs, J. L., \& Smith, G. T. (2014). An exploration of sexual victimization and academic performance among college women. Trauma, Violence \& Abuse, 15, 191-200.

Katz, A., Davis, P., \& Scott-Findlay, S. (2002). Ask and ye shall plan: A health needs assessment of a university population. Canadian Journal of Public Health, 93(1), 63-66.

Kilpatrick, D., Resnick, H., Ruggiero, K., Conocsenti, L., \& McCauley, J. (2007). Drugfacilitated, incapacitated rape: A national study. Charleston, SC: Medical University of South Carolina, National Crime Victims Research and Treatment Centre.

Kong, R., Johnson, H., Beattie, S., \& Cardillo, A. (2003). Sexual offences in Canada. Catalogue 85002XIE Vol. 23 No. 6. Ottawa: Juristat: Canadian Centre for Justice Statistics.

Koss, M., Gidycz, C., \& Wisniewski, N. (1987). The scope of rape: Incidence and prevalence of sexual aggression and victimization in a national sample of higher education students. Journal of Consulting and Clinical Psychology, 55, 162-170.

Krug, E., Dahlberg, L., Mercy, J., Zwi, A., \& Lozano, R. (2002). World report on violence and health. Geneva, $\mathrm{CH}$ : World Health Organization.

Lenskyi, H., \& Ontario Institute for Studies in Education. (1992). An analysis of violence against women: A manual for educators and administrators. Toronto, ON: OISE. 
Lincoln, Y., \& Guba, E. (1985). Naturalistic inquiry. Beverly Hills, CA: Sage.

McGregor, M., Ericksen, J., Ronald, L., Janssen, P., Vliet, A., \& Schulzer, M. (2004). Rising incidence of hospital reported drug-facilitated sexual assault in a large urban community in Canada. Canadian Journal of Public Health, 95(6), 441-445.

Minister Responsible for Women's Issues. (2015). It's never OK: An action plan to stop sexual violence and harassment. Toronto: Queen's Park Printer.

Mitchell, K., \& Freitag, J. (2011). Forum theatre for bystanders: A new model for gender violence prevention. Violence Against Women, 17(8), 990-1013.

Nicoletti, J., \& Spencer-Thomas, S. (2010). Building barriers to violence part 2: Developing policy and procedures for threats and violence. In J. Nicoletti, S. SpencerThomas, \& C. Bollinger (Eds.), Violence goes to college: The authoritative guide to prevention and intervention (pp. 81-126). Springfield, IL: Charles C. Thomas.

Ormiston, S. (Sep. 29, 2014). Universities under pressure to combat sexual misconduct on campus. CBC News. Retrieved from http://www.cbc.ca/news/universities-underpressure-to-combat-sexual-misconduct-on-campus-1.2781455

Pinchin, K. (2009). Sex-assault victim sues Carleton for negligence. Macleans Magazine. Retrieved from http://oncampus.macleans.ca/education/2009/o8/10/sexassault-victim-sues-carleton-for-negligence/

Rajacich, D., Fawdry, M., \& Berry, M. (1992). An institutional response to date rape. Canadian Journal of Higher Education, 12(2), 41-59.

Royal Canadian Mounted Police (2014). Missing and murdered Aboriginal women: A national operational overview. Ottawa: Her Majesty the Queen in Right of Canada.

Seifert, T., \& Borrow, T. (2013). Perceptions of student affairs and services practitioners in Ontario's post-secondary institutions: An examination of colleges and universities. Canadian Journal of Higher Education, 43(2), 132-148.

Senn, C., Eliasziw, M., Barata, P., Thurston, W., Newby-Clark, Radtke, L., Hobden, K., $\&$ SARE Study Team. (2014). Sexual violence in the lives of first-year university women in Canada: No improvements in the 21st century. BMC Women's Health, 14, 13-25.

Smith, P. H., White, J. W., \& Holland, L. J. (2003). A longitudinal perspective on dating violence among adolescent and college-age women. American Journal of Public Health, 93, 1104-1109.

Spencer-Thomas, S., \& Nicoletti, J. (2010). Building barriers to violence part 1: Amassing the army. In J. Nicoletti, S. Spencer-Thomas, \& C. Bollinger. (Eds.), Violence goes to college: The authoritative guide to prevention and intervention (pp. 74-80). Springfield, IL: Charles C. Thomas.

Statistics Canada. (2009). Victimization survey, general social survey cycle 23, tabulated data through ODESI (Ontario data documentation, extraction service and infrastructure). Ottawa, ON: Statistics Canada.

Sinha, M. (Ed.) (2013). Measuring violence against women: Statistical trends. Component of Catalogue 85-002-X Ottawa, ON: Statistics Canada. 
Taber, J. (September 5, 2013). Saint Mary's student president says rape chant was 'biggest mistake... probably in my life.' Globe and Mail. Retrieved from http://www. theglobeandmail.com/new/national/saint-marys-student-president-says-rape-chantwas-biggest-mistake-of-my-life/article14142351/

Tremblay, P., Harris, R., Berman, H., MacQuarrie, B., Hutchinson, G., Smith, M. A., Braley, S., Jelley, J., \& Dearlove, K. (2008). Negative social experiences of university and college students. Canadian Journal of Higher Education, 38(3), 57-75.

Universities: Search Universities Worldwide. Retrieved from http://www.univerzities. com/canada

UnivSource. Retrieved from http://www.univsource.com/canadaregion.htm

\section{Contact Information}

Elizabeth Quinlan

Department of Sociology

University of Saskatchewan

elizabeth.quinlan@usask.ca

Elizabeth Quinlan is an associate professor in the Department of Sociology at the University of Saskatchewan. She was one of the first doctoral graduates in the Interdisciplinary Studies Program at the University of Saskatchewan. Her research interests span workplace health, caring labour, and gender relations.

Allyson K. Clarke completed her Master of Arts degree and $\mathrm{PhD}$ in counselling/clinical psychology from the Ontario Institute for Studies in Education, University of Toronto (OISE/UT). She has a Bachelor of Arts Honours degree from the University of Saskatchewan and is a Registered Doctoral Psychologist, providing psychological treatment and assessment to clients with a range of presenting concerns. Allyson has a particular passion for research and practice in the area of trauma and recovery.

Natasha Miller completed her Bachelor of Arts Honours degree and Master of Arts degree in sociology from the University of Saskatchewan. Her research is in the areas of campus sexual assault and workplace harassment. 